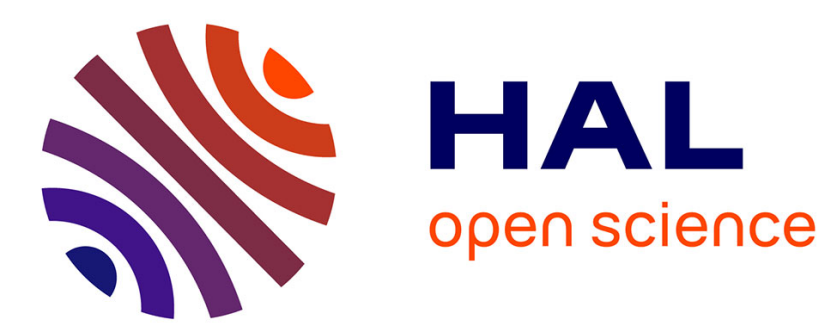

\title{
Territorialities, spatial inequalities and the formalization of land rights in Central Benin
}

Philippe Lavigne Delville, Anne-Claire Moalic

\section{To cite this version:}

Philippe Lavigne Delville, Anne-Claire Moalic. Territorialities, spatial inequalities and the formalization of land rights in Central Benin. Africa, 2019, 89 (2), pp.329-352. 10.1017/S0001972019000111. ird-02183773

\section{HAL Id: ird-02183773 \\ https://hal.ird.fr/ird-02183773}

Submitted on 2 Jun 2020

HAL is a multi-disciplinary open access archive for the deposit and dissemination of scientific research documents, whether they are published or not. The documents may come from teaching and research institutions in France or abroad, or from public or private research centers.
L'archive ouverte pluridisciplinaire HAL, est destinée au dépôt et à la diffusion de documents scientifiques de niveau recherche, publiés ou non, émanant des établissements d'enseignement et de recherche français ou étrangers, des laboratoires publics ou privés. 


\title{
TERRITORIALITIES, SPATIAL INEQUALITIES AND LAND RIGHTS FORMALIZATION (BENIN, WEST AFRICA)
}

\author{
Philippe Lavigne Delville and Anne-Claire Moalic ${ }^{1}$
}

\begin{abstract}
The formalization of "informal" customary land rights is at the core of current rural land policies in Africa. The dubious impacts of such policies on agricultural production, and the recomposition of land rights and governance they impulse have been largely studied. But their territorial dimensions are hardly acknowledged. Studying the implementation of a rural land rights formalization project in central Benin, this paper highlights the links between territorialization and plot level land rights formalization. It first unpacks the notion of village and presents a conceptual framework for analyzing the superposition and contradiction between customary and administrative territories. Mobilizing two case studies, it then studies the conflicts during formalization operations and their outcomes in terms of land rights mapping and political and administrative change This article shows how the political organization of the territory and the socio-spatial inequalities resulting from the history of settlement shape the results of plot level land rights registration (explaining why large parts of village territories have not been registered) and in return how these registration operations impulse new territorialization processes and increase the heterogeneity of land tenure rights inside the territory.
\end{abstract}

\footnotetext{
${ }^{1}$ Philippe Lavigne Delville is a socio-anthropologist and senior research officer at IRD (UMR GRED, Paul Valéry University/French Research Institute for Development, Montpellier, France). Email: philippe.lavignedelville@ird.fr. Anne-Claire Moalic is an agro-economist, and is currently consultant in rural development and land issues. Email: anneclaire.moalic@gmail.com.
} 


\section{Résumé}

En Afrique, la formation de droits fonciers coutumiers "informels" est au coeur des politiques foncières rurales contemporaines. L'impact discutable de ces politiques sur la production agricole, et les recompositions des droits et de la gouvernance foncières qu'elles induisent ont été largement étudiés. Mais leurs dimensions territoriales n'ont été jusqu'ici que peu prises en compte. A partir de l'étude de la mise en œuvre d'un projet de formalisation des droits fonciers ruraux dans le centre du Bénin, cet article met en lumière les liens entre territorialisation et formalisation des droits fonciers. Il discute d'abord la notion de village et propose un cadre conceptuel pour analyser les superpositions et contradictions entre territoires coutumiers et administratifs. A partir de deux études de cas, il étudie ensuite les conflits qui ont scandé les opérations de formalisation et leurs impacts sur les levés parcellaires et les changements politiques et administratifs. Cet article montre que l'organisation politique du territoire et les inégalités socio-spatiales qui résultent de l'histoire du peuplement façonnent les résultats des opérations de levé de parcelles (expliquant pourquoi de larges parts du territoire villageois n'ont pas pu être enregistrées) et que ces opérations induisent en retour de nouveaux processus de territorialisation qui accroissent l'hétérogénéité des droits fonciers au sein des territoires.

\section{Introduction $^{2}$}

Since the 1980s, farmers' land rights formalization has been the crux of international prescriptions on development policies in the Global South, and particularly in Africa (Manji 2006; Colin et al. 2009). In a context of economic liberalization and critic of the State, formalizing informal (neo)customary rights over land (that is mapping, writing and legalizing them) is supposed to secure these rights, reduce conflicts and allow for agricultural growth. Rural land rights formalization policies and operations in Africa have raised lots of controversies on their justification and timeliness (Bromley 2009), on their economic effects (Bruce and Migot-Adholla 1994; Platteau 1996), on the recomposition of land rights and governance (Chauveau 2003; Benjamisen and Sjaastad 2008), and, lastly on the ensuing risks of exclusion (Bassett 1995; Peluso and Lund 2011), particularly for women (Lastarria-

\footnotetext{
2 The authors thank Thomas Bassett, Denis Gautier, Baptiste Hautdidier and the anonymous referees for their comments on previous versions of this paper.
} 
Cornhiel 1997; Yngstrom 2002), pastoralists or migrants ${ }^{3}$ whose rights can be challenged under the argument of autochthony (Bosc et al. 1996).

Research on the social and political impacts of these operations in rural Africa highlights three main dimensions: the simplification of bundles of rights through the rights' identification and transcription (Bassett 1993; d'Aquino 1998; Musembi 2007); the recomposition of land tenure regulation, with the institution of new land tenure mechanisms either state-controlled or a hybrid of local and State authorities - which substitute (at least partially) to previous (neo)customary regulations ${ }^{4}$ (Hochet and Jacob 2014); and finally the redefinition of peoples' identities (Berry 1989), balance between local and national citizenships (Berry 2010; Hochet 2011) and State's local foothold (Lund 2006).

Indeed, "by defining the levels of authorities invested with the responsibility of identifying rights holders, validating rights assignments and settling disputes, or by regulating uses on specified areas, land tenure policy is a powerful tool for the reorganization of rural territories and, as such, for involving the State in local governance systems" (Colin et al 2009: 24, our translation and emphasis).

However, this issue of "reorganization of rural territories" through rights formalization is hardly addressed in literature (Benjaminsen and Sjaastad 2008). Focusing on land rights or on territories and power is not the same: "as territory, space is governed, but not owned by its governing agency. As property, on the other hand, space is owned, but not governed by its owners" (Lund 2013: 14). Little research has focused on the territorial dimensions of land rights formalization processes. Based on a plot level, land rights formalization does not require in itself to create new territories, contrary to other development or conservation projects that directly create new delimitations and new powers (Bassett and Gautier 2014). But cultivated plots are nonetheless located in territories, that are socially and politically differentiated and the bundles of rights held by the different stakeholders vary depending on the specific plot's location. Formalization processes have thus political issues and may also

\footnotetext{
3 The terms "migrant", "non-native" and "outsider" refer here to persons "foreign" to the local political community, and whose land tenure rights were delegated in a trusteeship relation (Chauveau 2006; Hochet and Arnaldi di Balme 2012; Le Meur 2012).

${ }^{4}$ In French-speaking countries, speaking of "le droit foncier coutumier" (i.e. customary land law) is ambiguous, since it too often conveys an idea of a coherent, fixed, set of rules while field research highlights norms that are changing and may be contradictory. That's why we prefer talking of norms or regulation for what could have otherwise been called "the local land law" and of land rights for the concrete rights held by individuals or family groups. In the same vein, speaking of (neo)customary rights highlights the fact that contemporary local rights are the product of history and change with demography, market, state intervention even when they rely on customary norms and/or authorities.
} 
lead to "unexpected territorialities" (Gautier and Hautdidier 2012). Territory is defined here a relation and outcome of the process of territoriality, that is an "attempt by an individual or group to affect, influence, or control people, phenomena, and relationships by delimiting and asserting control over a geographic area" (Sack 1986: 19). ${ }^{5}$ According to this definition, the attached concept of territorialization refers to specific territorial projects in which various actors deploy territorial strategies (territoriality) to produce bounded and controlled spaces (territory) to achieve certain effects (Basset and Gautier 2014). A goal of territorialization is to govern people and resources located within and around the territory (Scott 1998). Various sources of power, customary authorities (Godelier 1978; Kopytoff 1987) as well as states and empires have territorialization strategies, which interfere one on the other.

Drawing on the case of Plans Fonciers Ruraux (PFR - Rural Land Maps) in Benin, this paper ${ }^{6}$ aims at discussing the links between territorialization and land rights (individual or collective) formalization. Farmers land rights informality is the result of colonial and post colonial land policies which recognize only individual full ownership through a state led process of adjudication and titling, while putting all unregistered land under state control. This informality became considered as problem in the development doctrine at the end of the 1980s, in a context of economic liberalization and market valorization and of increasing critics of State interventions and power abuses in economy and society. While international institutions pushed for privatization and support to land markets (Manji 2006), other experts and aid agencies praised the inclusive and dynamic character of customary rights (Wily 2016) and asked for a legal recognition of such rights (Bruce and Mighot-Adholla 1994). PFR are one of the tools created in Africa to try to allow for such a legal recognition of customary land rights (Chauveau et al. 1998; Gastaldi 1998; Hounkpodote 2002). PFRs rely on a terroir approach?, assuming that a village terroir is made of contiguous plots held by individual or families. Such a conception confronts to customary often overlapping land rights, but also to complex and intertwined customary and administrative territories and to the diverse significations of what is a "village".

\footnotetext{
${ }^{5} \mathrm{~A}$ we will see, this issue of delimitation and boundaries may be problematic.

${ }^{6}$ Materials come from field studies by the authors in September 2013, April-June 2015 and January-March 2016 in the "Département des Collines" (Hills district), with an in-depth study of 6 PFRs.

7 The french term terroir lays emphasis on the cultivated area and avoids the political dimension of the territory. It relays on a conception of villages as agrarian units with a dedicated area. On the notion of terroir, see Painter et al (1994) and Basset et al (2007).
} 
The paper starts with a conceptual framework built upon the concept of "territorial frame", which allows for a systematic description of the various patterns of spatial socio-political organization - mainly customary vs state-led processes of territorialization - and their superposition or contradictions. Then follows an analysis of the implementation of PFRs in two villages of the Département des Collines in Central Benin, and an assessment of how such implementation, which is expected to survey an entire village terroir, is confronted by the socio-political organization of village territories and the possible discrepancies between customary and administrative territorial frames. In practice, surveys were never exhaustive. Only a fraction of the village terroir could be surveyed, particularly as a result of the prohibition on the inhabitants of some hamlets registering in the PFRs. In return, PFRs increase spatial inequalities, in the sense that the rights of autochthons and of some migrants could be registered and could eventually gain legal recognition, while those of other groups, owing to their social and tenural standing and the status of the hamlet where they live, are excluded. Implementation of the PFRs thus leads to an expansion in the range of land rights, and creates a new territory - the registered area -, enhancing the heterogeneity of territories and reinforcing spatial inequalities between different groups of actors.

\section{INTERTWINED TERRITORIES AND DEVELOPMENT PROJECTS:}

\section{A CONCEPTUAL FRAMEWORK}

In Central Benin as well as in most places in West Africa, the notion of "village" covers variable dimensions. It does not bear the same meaning and does not always cover the same space in the customary and administrative perspective. In both cases, powers delimit specific areas upon which they exert some control over human settlement and uses. In both cases, territories are made up of a political centre and dependent hamlets. But they do not constitute a homogeneous entity in any of the two systems of meaning. To describe and understand the superimpositions and disjunctions between these two kind of territories, we will use the concept of territorial frames which was suggested in a study on land tenure issues in lowlands development schemes in Burkina Faso and Mali (Lavigne Delville et al. 2000: 17-24), drawing on the notion of land tenure frame laid out earlier in studies on terroir management in Burkina Faso (Bouju 1991; Bouju and Brandt 1989). This study showed that part of the conflicts provoked by the lowland development schemes were linked to their specific location in territorial frames and the related competition in decision power. 


\section{Customary territories, administrative territories: intertwined frames}

From an internal frontier perspective (Chauveau et al. 2004; Kopytoff 1987), the history of settlement in segmentary societies involves people migrating and settling in new places, either by being hosted by first comers already settled, or by ritually creating a new political center8, exerting a control over a given area. Such a control rely on a topocentric logic (Bohannan 1963) structured around the center whose capacity of control declines with the distance, and not on a geometric approach defined by the borders. New comers are accommodated by the first settlers. They may be considered as autochthons, if they arrive when space is still largely available, or settled as "strangers", incorporated in the local community with a subaltern social position (Hochet 2011). Such processes lead to the coproduction of political communities and territories (Chauveau et al. 2004) around foundation areas. Settlement processes results in the creation of a set of chiefdoms comprising a central village and a series of hamlets. The central village, which is the seat of customary power is politically autonomous, even though it maintains political and family ties with the village of origin of the founder, and frequently falls under larger political divisions. Hamlets are established in the course of settlements. Founded with the agreement of the customary authorities of the central village, they can be populated with groups coming from this central village but are often created by migrants from diverse origins. Their relationships with the central village and the chiefdom vary according to the content of the foundation pact - itself linked to the social status of the constituent groups and their ties with the chiefdom and to land scarcity at that time - , and subsequent developments and renegotiations. The local political communities are thus organized around the supremacy of a founding lineage and sometimes of privileged allies, based on a village structure which can be of mono- or poly-lineage (Le Meur 2006). The other social groups, recent or long-standing migrants settled in the central village or in hamlets, are associated to the former (and sometimes to the older migrants) through a "tutorat" relation (Chauveau 2006) at varying degrees of political and related rights to land (Hochet 2011). Ultimately, it is the central village and all the hamlets established by the chiefdom or one of the founding lineages which define a customary political territory (which may not be contiguous).

The village territory (central village and its hamlets) is only partially delineated. Some of its boundaries, particularly the natural ones (hill, water course) are defined. Artificial markers are placed at certain strategic areas, but the borders are not always defined, particularly in

\footnotetext{
${ }^{8}$ See for example for the Dagara in Burkina Faso, Kuba and Lentz (2002).
} 
uncultivated areas separating two villages, and serving as land reserves for the future needs of villagers. Installing migrant hamlets at the periphery of territories is a frequent strategy for asserting control on it.

Borders can be indefinable where, at the cross-roads of two pioneer fronts, the terroirs overlap and neighboring plots are cultivated by inhabitants of different villages or hamlets. The territory is further recomposed with the evolution of the settlement, the extension of cropping areas, the installation of new hamlets at the boundaries, etc.

These often intertwined customary territorial frames are superimposed by administrative frames linked to State attempts to control and organize its territory: some places are defined by the State as administrative villages while others are administrative hamlets attached to an administrative village. The administrative boundaries themselves are not always clearly defined and the territory of an administrative village is in practice defined by the series of places of human settlement that are attached to the administrative village center. Similarly, it is the list of villages belonging to the commune which defines the communal territory.

Because they have grown to attain the required size and seek to gain more autonomy from the administrative village on which they depend (mainly to benefit directly from infrastructures), many administrative hamlets (of variable customary status) are requesting to be upgraded into administrative villages. Given that their population have grown enough, the headquarters of customary chiefdom, a hamlet of autochthons or a hamlet of migrants under customary trusteeship, can become administratively autonomous.

Hence, there is a continual dynamics of administrative territories, separated by administrative divisions with a strong political component: over and above the population size, relations with the national political power were historically, and still are, decisive in the possibility for an administrative hamlet to gain recognition as an administrative village. Depending on the State's political strategies towards the local authorities, and the standards for accessing to the status of an administrative village, customary and administrative territorial frames overlap, crisscross or contradict each other. It may mirror or oppose the spatial customary organization; a customary political central village may be an administrative village or a mere administrative hamlet attached to another administrative village. Each dwelling area is thus involved into a dual relation of autonomy and dependency, depending on its status in the settlement history and the administrative division.

Figure 1. Representing territorial frames 
Such relations can be figured on a simplified representation of customary and administrative territorialities at micro-regional level (figure 1), localizing villages and hamlets, with their political status in both rationale and their relations in both territorialities. Just like a fabric is made up of intertwining yarns, the notion of frame highlights overlapping approaches, the superimposition and recovery of different territories and forms of political control over space. It recognizes the topocentric dimension of territories, the frequent lack of defined boundaries and the fact that territories are first defined through the ties linking the various constituent settlement areas. It allows to characterize these human settlements relatively on their position in these dual customary and administrative territorialities, and to identify the conjunctions and disjunctions between the two types de territories (superimposition or discrepancies between customary and administrative dependency relations). Therefore, it is possible to situate the challenges of a given development intervention in this dual political configuration. ${ }^{9}$ Making a distinction between "old" and "news" hamlets is clearly a simplification. It assumes that older hamlets may have stronger rights due to thicker relations with autochthonous lineages, but also relates to different waves of migration and different settlements pacts with customary authorities.

\section{Development projects and unexpected territorialities}

As long demonstrated by social anthropology, any development intervention is "an intervention in dynamic systems" (Elwert and Bierschenk 1988) and has significant political challenges in local arenas (Olivier de Sardan 2005). Much more, the location of an infrastructure or facility is not neutral; it takes a specific place in politically and socially differentiated territories. In the case of lowlands development schemes, Lavigne Delville et al (op. cit) showed that the risks of conflicts were clearly linked to territorial configurations. Local elites in a land hamlet upgraded into an administrative village could attempt to negotiate a development scheme directly with the development project, without prior negotiation with the customary authority they depend of, , at the risk of starting a conflict with it, in a strategy of political emancipation and territoriality. In the case of village-based forest management policy in Mali, Gautier and Hautdidier (2012) showed how such policy, focused on uncultivated area with few territorial control or land claims, impulse new claims and the

\footnotetext{
${ }^{9}$ Treating villages and hamlets as if they were homogenous and coherent entities is tantamount to simplifying the reality. Strictly speaking, it would be necessary to include the lineage level into the analysis of relations between autochthons and migrants, and to add the lineage land tenure frames to the territorial frames.
} 
creation of new "unexpected" territories that interfere with existing customary as well as with state territories.

These two cases call for a more systematic analysis of territorialization issues in development projects. That's what we will now do, mobilizing this analytical framework to study how PFRs operations interfere with existing territories and produce news territorialities.

\section{TERRITORIALITIES AND CONFLICTS}

\section{IN THE IMPLEMENTATION OF RURAL LAND MAPS IN CENTRAL BENIN}

PFR are based on the identification and mapping of farmers' land rights, at village level, leading to a plot map and a register of right holders. Their focus is on individual or collective land rights, not on territory or sovereignty. ${ }^{10}$ But they also raise issues of territoriality: PFRs are supposed to cover the full village terroir and to produce a systematic map of existing customary rights. Recorded rights are then supposed to receive a land certificate and to be governed by a new "village land management committee", in links with a commune level land administration body. They are implemented at administrative village level and rely on a dubious conception of villages as autonomous entities, having their own terroir, with contiguous plots belonging each to individuals or family groups. Such a conception necessarily confronts the existing customary territorialities and superimposed land rights, possibly creating new unexpected territorialities and new sources of exclusion.

\section{The Département des Collines, from a sanctuary to an immigration area}

The Département des Collines and more extensively the Centre of Benin is historically situated between the Kingdoms of Danxomé in the South and Borgou in the North. This region was a refugee area for various social groups trying to escape the insecurity and/or political domination of these kingdoms during the enslavement raids perpetrated by the Danxomé kingdom. Because of its resultant relative under-population, this region became a heavy immigration area in the $20^{\text {th }}$ century, with pioneer fronts moving generally towards the east and then to the north-east, where they are still active. The long settlement history is eventful, with many displacements, migrations, founding and abandoning of villages, and seems to be characterized by a particularly free flow of dwellings and relationships based on patronage (Anignikin 2001; Le Meur 2006; 2012). The Département des Collines is roughly

\footnotetext{
${ }^{10}$ See Lund (2013) for a discussion of these two dimensions of space.
} 
made up of two major settlement areas, Nago-Tchabé (linked to Yoruba groups) and MahiIdaatcha (linked to Adja-Fon groups), with more recent migrants of Fon origin or from Atacora.

Implementation of Rural Land Maps in the Dassa-Zoumè and Savalou communes: arrangements, rough job, conflicts, approximations ${ }^{11}$

Invented in Côte d'Ivoire, PFRs have been experimented in Benin since the early 90s, in an attempt to build an alternative to individual land titles and privatization. PFR were supposed to increase tenure security by allowing for the registration of legitimate and socially recognized rights - either individual or collective - and avoiding conflicts due to oral informal agreements. Methodology has been designed through pilot projects between 1992 and 2005 (Edja and Le Meur 2009; Lavigne Delville 2009). However, the issue of rights transformation through registration has not really been dealt with by project teams (Le Meur 2011). A legal reform passed in 2007 allowed registered right holders (individuals or family groups) to receive a "rural land certificate" attesting the rights held on their plots (Lavigne Delville 2010a). PFR have then been implemented on a large scale: 300 PFRs were drawn under a USfunded project implemented by MCA-Benin between 2007 and 2011, among which 12 in Dassa-Zoumé and Savalou communes, in central Benin (Lavigne Delville 2014b).12 Due to different reasons (brutal end of the project, mixed interest of farmers, bureaucratic constraints, new legal change), few certificates have been issued. Our analysis thus focuses on the mapping stage of the formalization process and not on subsequent issues related to land certificates' access and use.

According to the methodology, a PFR is undertaken only in volunteer villages; operations are by specialized teams of land surveyors and land rights specialists (sociologists, geographs, etc.); they carried out with the support of a local committee managing villagers' information and work organization. The plots are surveyed one after the other until the entire terroir is covered. Plot survey is conducted in the presence of right holders and neighbors. Plot limits are delineated and right holders are interviewed on the origin and content of their rights. Individual plots are registered in the name of the owner, collective plot in the name of the family group or the family head (identified as the "land manager"). Other rights holders

\footnotetext{
${ }^{11}$ For a more detailed analysis, see Moalic (2014).

${ }^{12}$ Other projects financed by German or Netherland aid also implemented PFR in other regions.
} 
(family users, people having negotiated derived cultivation rights ${ }^{13}$ ) are also supposed to be recorded. Survey formulae are signed by right holders and neighbors.

However, an in-depth analysis of practices reveals a much more problematic process, with multiple distortions vis-à-vis the stated willingness to produce a "snap-shot" of the rights ${ }^{14}$ and an exhaustive survey of the terroir. Transcribing the oral and flexible rights embedded in social relations into predefined categories raises lots of conceptual issues (d'Aquino 1998). Each transcription stage is potentially subject to bias and reinterpretations because of the categories selected, the cognitive frameworks and the interests of technicians, as well as local political challenges. ${ }^{15}$ Transcription is at the same time a translation, a partial redefinition (Le Meur 2011), and the emphasis on the "participatory" dimension does not allow avoiding bias. Categorizing right holders in terms of "owner/family manager" and "other right holders" do not fit the complex overlapping rights. Moreover, who can be registered or not is partly the outcome of negotiations within local arenas. Announcement that a PFR would be made in a given village led to lots of discussions within family groups and at the level of customary authorities, to know how to respond to the team, anticipate risks, and decide on how to handle the issue of family plots, land reserves and migrants' hamlets.

The implementation of the PFRs was also hampered by frequent conflicts which blocked the operations, until negotiations were conducted and compromises were reached. ${ }^{16}$ Most of the conflicts pertained to the situation of hamlets and their inclusion or not into the PFR. Contrary to the stated ambition to survey the entire village territory, the area registered under the PFR represents only a variable part of the territory. Within the blocks of surveyed plots, there are still gaps, parcels or areas not yet surveyed. In between blocks, or around same, the map leaves large blank spaces: around the portion of territory which has been surveyed, but also within the PFR surveyed area (in pink hachures on the maps below).

Figure 2. PFR map and unsurveyed areas (Miniffi)

\footnotetext{
${ }^{13}$ Derived or delegated rights encompass the full range of arrangements allowing people to gain cultivation rights on plots owned or controlled by another family. It covers long term transferable use rights granted to a "stranger" through a tutorat agreement, as well as shorter contracts like rent or share contracts (Lavigne Delville et al. 2002).

${ }^{14}$ On the illusion of the snap-shot, see Chauveau and Lavigne Delville (2012).

${ }^{15}$ See figure in Lavigne Delville (2014a : 13).

${ }^{16}$ Twelve PFRs were planned in the Dassa-Zoumè and Savalou communes, in the Département des Collines. Two were cancelled as a result of conflicts caused by the start of activities.
} 
The official explanation given for such a partial survey is lack of time: having barely three months per village, the teams could not complete their work, which was heavier in large villages with many small plots. Moreover, delays in the signing of contracts with service providers, practical issues (rains, people's migration), repeated absences of the beneficiaries and conflicts prolonged the work. In fact, there has been a combination of time constraints and political rejections. PFR maps thus have many gaps, and an in-depth analysis shows about ten different causes: refusal to register one's parcel, owners absent, non-regularized purchase, areas under dispute, portions of customary territory outside the administrative boundaries, areas exploited by long-established migrants or hamlets related to other customary territories, land reserves, etc.

\section{Territories, migrants, spatial inequalities and PFRs}

The future of the lands situated around migrants' hamlets crystallized most of the conflicts. The ambition to survey the entire village territory is based on the representation of the village and its territory as coherent and homogenous. Such representation, as seen earlier, is problematic regarding the realities of agrarian and political territories, in which the governance of human being and of nature cannot be separated (Chauveau et al. 2004).

One of the issues raised in rights formalization in a customary situation is that such processes are most of the time based on an oversimplified conception of land rights that does not take into account the bundle of rights and the diversity of right holders. Drawing on an ownership conception, they assume that there is a customary "owner" or "possessor" for every plot, and that other people having cultivation rights are only simple "users". As we saw, in Benin, PFR methodology makes a double distinction between "collectively held plots" and "individually owned plots" on the one hand, and "delegated right holders" on the other hand. This distinction acknowledges the existence of family land heritage, but cannot explain the reality of superimposed rights ${ }^{17}$ that are not limited to two levels of rights, one of which (user's) cannot claim ownership. It is also problematic in the sense that the category of "delegated right" encompass very different situations: a young household head cultivating part of an

\footnotetext{
${ }^{17}$ See figure in Lavigne Delville (2010b : 21).
} 
extended family holding, an neighbor having rented a plot, a son of a migrant cultivating a plot granted to his father as permanent transferable rights, are not in the same situation.

Such a conception raises issues on who will be registered and the subsequent redefinition of other right holders, event within autochthonous families: what about younger children's and women's rights? What about heads of households who enjoy permanent and transmissible rights of usage on a joint family property? The stakes are even higher when it comes to migrants: registering a parcel poses the problem as to whom, among the descendants of those who granted the farming right to the new comer or the descendants of those who benefitted from that right, can be recognized as the principal beneficiary. In customary logics, the permanent and transmissible user rights held by migrants or their descendants coexist with rights of the tutors on the land that they have historically granted. Along time, migrants and their descendants practically consolidate their rights without any other restriction than the symbolic recognition toward the lineage that historically settled them. Conversely, autochthonous lineage control over granted land remains but becomes practically symbolic: the plot cannot be taken back.

The obligation to state in whose name the lands are registered forbids staying in a situation of superimposed rights. For the autochthonous lineages, letting migrants have their land rights registered in PFRs would mean accepting to definitively forfeit control over the lands they had hitherto granted, on which they no longer have any power in some cases, but which formally remain "theirs". Will these autochthonous lineages seize the opportunity of the PFR to reassert their rights on such lands, become the legal owners thereof, even if it means undermining the rights of migrants, and reducing them to mere users of the lands of another person? Are the latter ready to accept such a redefinition of their rights? The issue does not really concern recent migrants whose status as farmers on the lands granted them by autochthons is not questionable, as much as the older migrants who have consolidated their rights of usage, transmitted them, and may even have settled other migrants.

The issue of the future of the rights of migrants, both old and recent, in PFR operations, is even more pregnant where the migrants have established hamlets, with relative autonomy in daily land management. The stakes are not related to land tenure issues only (i.e. linked to property rights of individuals and families). They are also political and territorial, both because the registration of migrants in the PFR implies the recognition of their full rights on the land which, theoretically, is the monopoly of "autochthons", and because the political 
control of hamlets determines the control of the surrounding territory. Allowing migrants' rights on land to be registered would mean accepting to lose this control.

PFRs thus engage territorialities. They can be an opportunity for autochthonous lineages to maintain or reinforce their political power over the territory and its margins: when migrant hamlets are under the control of the same customary and administrative village, they have few to say. But in the case of two different and contradictory territorial controls, migrants can try to negotiate administrative support against customary authorities and claim for being registered. Thus PFR represents an opportunity to challenge existing power relations and recompose territorialities.

These issues are all the more severe that the "village" benefitting from the PFR is a customary hamlet upgraded into an administrative village. It was seen earlier that such an administrative village can have a terroir in the sense of an area exploited by its inhabitants, but has only limited autonomy over land tenure, with no territory as such, customarily speaking. Administrative villages are the operating unit for PFR, but their political and land tenure positions and the ones of their constituent hamlets, are very varied. This gives room for contingent and possibly diverse responses between "villages" and within the same "village", responses stemming from negotiations and power struggles.

\section{RURAL LAND MAPS, MIRROR AND PRODUCER OF TERRITORIES: TWO CASE}

\section{STUDIES}

We will discuss these issues through two case studies on the reorganization of rural territories following PFR operations. The localities selected for the study are Miniffi and Assiyo, in the Dassa commune. They represent two different configurations: as a powerful customary central village, but also an administrative village, Miniffi has experienced several overlapping administrative territorialities on its customary territory; conversely, Assiyo, which is a former migrants' hamlet upgraded into an administrative village, has an administrative territory build upon parts of several customary territories. Both villages have witnessed tensions or conflicts during PFR operations, involving the use of weapons and the theft of PFR teams' equipment. It will be seen that the conflicts occur where territorialities are conflicting and that areas surveyed under PFR partly translate the spatial heterogeneity of the territory. Conversely, it will be seen that implementation of the PFR and the ensuing trade-offs contribute to recomposing the territories, introduce new land tenure distinctions and new territories, producing new spatial inequalities. 


\section{Miniffi, customary central village and administrative village}

Miniffi is an ancient Mahi chiefdom of the Dassa-Zoumè region, comprising four major autochthonous lineages. It is also an administrative village attached to the Soclogbo subdivision. It comprises about twelve hamlets under customary trusteeship, with different statuses. Situated in the north, Akoba, an Idaatcha hamlet, was upgraded into an administrative village in 2010. The customary authorities of Miniffi approved the upgrade so that Akoba could benefit from infrastructures, on condition that they respect their land tenure prerogatives. The authorities of Akoba however complain that the people of Miniffi come to farm on lands belonging to Akoba, behind the hill which, according to them, delineates the lands controlled by Miniffi inhabitants.

One of the hamlets, Lanmanou, customarily installed by Miniffi south of its territory, was founded by Idaatcha natives from neighboring regions. Although administratively integrated into the village (particularly in terms of access to collective equipment), in 1991, it was electorally attached to the village of origin of the founding lineages, Léma, which is equally the headquarter of the sub-division bearing the same name and located about 50 kilometers away from Lanmanou. This prefectural decision was taken in response to a dispute between the contiguous communes (upgraded into sub-divisions) of Gbaffo and Soclogbo, given that Lanmanou is situated at the border between these two sub-divisions. Gamba, a hamlet of Idaatcha migrants who came from Léma, also established on the customary territory of Miniffi, was counted under the polling station of the Idaatcha village of Banigbé, distanced by only about a dozen kilometers from Gamba and attached to the Akoffodjoule sub-division. These hamlets are thus electoral pockets of other sub-divisions, included in the administrative territories of Miniffi and Soclogbo sub-division.

Figure 3. Territories of Miniffi in 2010

The Gamba hamlet had itself established a hamlet of Fon migrants on its territory, Savalou Doho. During PFR operations, the authorities of Miniffi offered to the inhabitants of Savalou Doho to have their lands registered in their name. Savalou Doho accepted to register its farmed land in the PFR as a gift from Miniffi, which confirmed their attachment to Miniffi customarily and administratively. The lineages of Gamba saw in this attempt a pretext for Miniffi to try and recover part of the lands they had granted them, and a strategy to weaken 
the electoral and hence political strength of their hamlet. They blocked all land tenure operations in Savalou Doho by stealing the equipment of land surveyors and by provoking clashes that left a few people injured. Gamba inhabitants tried to garner political support and form an alliance of Idaatcha hamlets established on the customary territory of Miniffi, such as Lanmanou, Madolo, Srouhedji and Témidjiré, in order to mount pressure against the PFR and thus have more weight in the balance of power with Miniffi. As a result of the conflicts, the close to ten inhabitants of Savalou Doho left the hamlet and went away. And the lands exploited by the Idaatcha hamlets between Gamba and Lanmanou were not surveyed.

Part of the land around the Srouhedji hamlet was included into the PFR, with parcels registered in the name of Miniffi autochthons, thus creating a new difference between the autochthons whose lands were surveyed and the others, between hamlets included in the PFR and on which autochthon land control was reinforced and the others who refused to register or who were denied registration. The same scenario occurred even within these hamlets, between the majority of inhabitants and the rare persons who succeeded in registering the lands they control in their name. ${ }^{18}$ The area registered under the PFR therefore comprises the customary territory of Miniffi, less the lands exploited by inhabitants of Akoba, who are not part of its administrative territory, less the neighboring lands of the Gamba and Lanmanou hamlets (fig. 5) and part of Srouhedji, which belonged thereto at the time of PFR operations.

\section{Figure 4. Territories, conflicts and areas surveyed under PFR in Miniffi}

The tensions around land control between migrants and autochthons, ignited by the PFR which obliged to define the notion of "ownership", were politicized in the electoral competition between Mahi and Idaatcha at sub-divisional level. ${ }^{19}$ As political affiliations often follow ethnic ties, the ethnic composition of electoral units may influence the political balance in elected bodies. In Bénin, commune councils are made of "arrondissements" (sub commune level) representatives. Changes in the composition of the arrondissement may thus change the power balance at this level, and eventually at commune level, leading to frequent

\footnotetext{
${ }_{18}$ Hence, at Lanmanou, one person succeeded in having his parcel registered despite pressure from Idaatcha members of Lanmanou and the neighbouring hamlets that were against the PFR.

${ }^{19}$ Changing the attachment of a populated hamlet to a sub-division also changes the electoral balance in the two sub-divisions concerned.
} 
renegotiations in administrative frames and gerrymandering. The contradiction between administrative and electoral attachment of Miniffi's hamlets are a result of such issues. The conflicts linked to the PFR allowed the hamlets of Srouhedji, Lanmanou and Gamba to contest their administrative dependence toward Miniffi. Thanks to the support of an Idaatcha politician, there were upgraded into administrative villages in 2015. The Idaatcha hamlets became politically autonomous within the customary territory of Miniffi, and the administrative territory of the village was highly reduced. The political tension between the village of Mahi and Idaatcha hamlets had been ongoing prior to the drawing of the PFR, as testified by the specific position of Gamba and Lanmanou in the electoral constituency. However, this recomposition was clearly triggered by the conflicts around the PFR.

\section{Assiyo, land tenure hamlet upgraded into an administrative village}

In the early $20^{\text {th }}$ century, Assiyo was established by an Idaatcha family group whose rights to clear and cultivate had been granted by the Mahi customary authority of Lissa. Assiyo developed with the arrival of other family and migrant groups. Some Idaatcha lineages that arrived earlier on later welcomed Fon migrants, who created the small settlement groups of Aïdjesso and Abagon at the crossroads of the clearing fronts of Assiyo and Gbohouélé. In 1984, Assiyo became an administrative village. Because it had no boundaries, its administrative territory included the hamlets under the customary supervision of Gbohouele (the Cozo hamlet) and Lissa (the hamlets of Adjanoudoho and Yawa II) and encroached on the customary territories of the chiefdoms of Gbohouele and Lissa (and to a lesser extent, Gonsoue through the lands of a lineage that hailed from Lissa and settled in the village).

\section{Figure 5. Territories in Assiyo}

Assiyo is thus a customary hamlet upgraded into an administrative village and which, as such, despite the creation of a land chief when it obtained its autonomy, has a terroir with cultivation rights but no customary territorial control over its lands and remains dependent on Lissa for land matters. 
The customary and administrative authorities of Lissa and Gonsoué had initially refused that the PFR be carried out in Assiyo, arguing that it was just a hamlet of migrants. After much negotiation between these villages, they agreed as follows:

- Assiyo could carry out the PFR, but only families resident in the central village of Assiyo could register farmed lands in their names;

- Two plots representing a surface area of 300 ha were registered in the name of the chief of the Lissa administrative village, who is a member of one of the autochthon lineages of Lissa;

- Prior to the PFR, a family group from Gonsoué had sold 110 ha of apparently uncultivated land situated on the administrative territory of Assiyo, unbeknownst to Assiyo's leadership. Challenged by the village chief who had not signed the sales agreement, the sale was under dispute before the Dassa-Zoumè council. In exchange for the agreement by its customary trustees over the elaboration of the PFR, Assiyo accepted to drop the legal proceedings concerning the sale. The descendants of the founding lineage of Gonsoué also succeeded in registering in their name the lands under their control on the territory of Assiyo, which they had sold.

Besides these arrangements, the autochthonous lineages of Lissa and Gonsouè exerted pressure on the chief of Assiyo village to prevent the hamlets of Adjanoudoho and Yawa II, established by Lissa and situated on the administrative territory of Assiyo, from registering their lands. These lineages had sold lands in this area, and had ongoing sales negotiations within the territories of these hamlets. They were aware that if the families of these hamlets could register in the PFR and have a rural land certificate, they would lose control over these lands and the possibility to sell them. The agreement remained tacit and, at the level of the hamlets, the administrative authorities of Assiyo and Lissa explained that the lands were not registered due to lack of time.

Some migrants settled at Abagon and Aïdjesso, Fon hamlets established by Assiyo about 50 years ago, succeeded in registering in their name the lands they were exploiting at the boundaries overlapping with Gbouhouélé, either by negotiating with their owners, ${ }^{20}$ or with a view to securing Assiyo's control over these lands. The settlement areas of the hamlet are situated on the administrative territory of Assiyo, but some of the lands exploited by their

\footnotetext{
${ }^{20}$ At Aïdjesso, an owner authorized the farmer to register the land on which he had sown on condition that the latter pays him the sum of CFA F 10,000 (€15).
} 
inhabitants had been given by lineages of Gbohouele. These farms which are close to Abagon, are administratively attached to Assiyo. During PFR operations, some persons linked to Gbohouele called for an end to the survey of parcels in the area concerned.

\section{Figure 6. Territories and PFR in Assiyo}

The customary authorities of Lissa could not prevent the design of the PFR on Assiyo, which is an administrative village. Likewise, they could not claim registration of their historical lands in their name and prevent families residing in the headquarters from registering the lands they were exploiting. However, they gave conditions in their agreement: ban on registering lands in the hamlets established by Lissa, and registration of land in the name of the chief of Lissa village. ${ }^{21}$

Following PFR operations, some migrants of Aïdjesso, whose cultivated lands were registered under the PFR by their Assiyo trustees, were denied access to the land as a result of the sale thereof by their trustees without prior notice to the farmers. The territorial inequality caused by the exclusion of the hamlets of Yawa II, Adjahoundoho and Cozo from the surveys was compounded by inequalities between those who managed to negotiate registration in their name (in Abagon and Aïdjesso), those who could not register and those whose lands were registered in the name of their former owner. As a result, Assiyo inhabitants gained full control over the land they cultivate and Assiyo now has its own cultivated territory, made by the plots that have been recorded in its PFR. However, this territory is limited to the lands situated around the village and does not cover its administrative territory.

\section{CONCLUSION}

The territoriality strategies engaged around the Rural Land Maps in Central Benin reveal their social and political challenges. Struggles for being registered (or for forbidding other to be registered) are shaped by territorialities and contribute to shape territories, reorganizing existing territories and creating new ones.

\footnotetext{
${ }^{21}$ The majority of people interviewed ascribe the absence of surveys around Cozo to a lack of time by the team and not to hindrances. However, the remoteness of Cozo and the overlapping of territories are also highlighted by some of the persons interviewed. This could have contributed to the fact that this area had not been prioritized and one may be inclined to think that land tenure operations in this area could not have been carried out without the authorization of Gbohouélé.
} 
As a previously refuge area from enslavement raids which was resettled after the end of the slave trade and became a land of emigration and later of immigration, the Département des Collines is symptomatic of territorial configurations based on interrelationships of political affiliations and dependency in land tenure. For centuries, the territorial construction in central Benin and particularly in the Département des Collines came about through the mobility of social groups and a set of successive settlements framing composite customary territories with unclear or renegotiated borders. Result of state territorialities and local political negotiations, the likewise unsteady administrative divisions confirm, recompose or seek to dislocate them. Customary and state territorialization strategies follow different logics and interfere, sometimes comforting some time contradicting each other.

Aimed at registering customary land rights, PFR operations rely on a simplistic design based on: (1) a topographical and legal representation of land tenure - an individual or collective land owner, and family farmers or delegated rights holders; and (2) a representation of the village as a homogenous entity, made up of juxtaposed farm holdings, which covers a terroir composed of the lands exploited by its inhabitants. Registering rights over land means defining, in these multiple chains, who can claim (individual or collective) "ownership" at the risk of undermining the right of other right holders. This issue is particularly strong for migrants, especially the long-established migrants, who have practically consolidated permanent and transmissible rights, but not full and complete ownership rights. Depending on the power balance, PFRs may have allow them to be fully recognized by the State, or instead, allow the autochthonous lineages to reaffirm a control on lands on which they were no longer exercising power, thus weakening migrants' rights.

But struggles about PFRs are not only an issue of property rights. They also engage territorialities, contradictory strategies to control a geographical area. Territories are heterogeneous and the specific location of one plot is not neutral regarding the rights at stake and the political issues of land rights formalization. In the case of hamlets, the land rights registration issues become compounded by political challenges and territorial issues: reasserting customary control over territorial margins, checking the hamlets' attempts at gaining political autonomy. PFRs impulse contradictory territorialities; they impulse struggles and negotiations about the portions of territories that can be surveyed and in whose name this can be done.

During PFR operations, the possibility for hamlets to get their lands registered led to discussions and negotiations. Conflicts broke out, delaying or blocking the operations. These 
renegotiations had various outcomes, but led generally to a strengthening of the autochthons and non-natives dichotomy. Families of autochthon hamlets had no difficulties to get registered. The lands exploited by households of recent migrant hamlets were registered in the name of autochthonous lineages that settled them therein, with sometimes a renegotiation of the rules (for instance, strict acceptance of a ban on tree planting, which was hitherto unclear). Exceptionally, migrants in a particularly consolidated situation, who had planted trees a long time ago, and/or who have strong political ties, succeeded in being recognized as landholders and registered in their name the lands they were cultivating at the time of the investigations; hamlets of migrants succeeded in being proposed registration in their name where this made it possible to consolidate the strategies of territorial control over margins with uncertain status.

Lands that had been granted long ago to inhabitants of old migrant hamlets were, in rare cases, registered in the name of the migrants. But they have often been registered in the name of autochthonous lineages all the more easily as they concerned parcels in fallow or ancient fallows that were not being cultivated at the time of PFR operations. Where the lands had been cultivated or let to lie fallow recently, such lineages thus regained rights that had been highly diluted over time, at the expense of jeopardizing those of migrants. Where the situation of migrants was sufficiently consolidated to prevent survey in the name of autochthons, the parcels were not surveyed in anybody's name, leading to the "blank spaces" on the plot maps. The PFR thus induces a partial renegotiation of land rights, generally to the benefit of autochthonous lineages. The balance of power between migrants and autochthons, between customary hamlets and the central village, depends on migrants' location within customary and administrative territories.

Territorialities and disjunctions between administrative and customary territories contribute to shape the impacts of PFR. They explain why violent conflicts arise in specific locations, and parts of the village (administrative) territory surrounding these locations could not be registered. Conversely, PFR open space for territorialisation strategies and contribute to reorganize territories, when migrants succeed in using these disjunctions to strengthen their political and tenural autonomy. In Miniffi, the struggle led to the erection of migrants' hamlets as administrative village, strongly reducing Miniffi's administrative territory and 
challenging customary control on these new territories. In Assiyo case, an administrative village former customary hamlet, PFR resulted in a creation of a village territory. ${ }^{22}$

As PFRs are unable to cover the full village territory, they also create new unexpected territories, the "PFR registered territory", that is the area that has been surveyed. Having one's plot registered in one's name in the PFR (and later being able or not to obtain a land certificate $^{23}$ ) is a new source of divide in the landscape that cuts across the autochthons/migrants divide. This new territory is the result of the competing territorializing strategies opened by PFR, which result in new categories of migrants in terms of land rights: those whose land has been registered in their own name, those whose land have not been registered, those whose land has been registered in the name of autochthonous lineages. These new categories increase social differentiations and identities, on a territorialized basis. Inside registered people, being able or not to obtain a land certificate creates a new source of differentiation. ${ }^{24}$

PFRs are based on the premise of recognizing legitimate existing rights while favoring autochthon conceptions in practice, considering the administrative village as the unit of intervention, not addressing the issue of spatial inequalities and their challenges. They ultimately fall in line with the State's long-term attempt to strengthen its local foothold and recompose the local power and territorial authorities around administrative villages. However, as for other state reforms (Bierschenk 2014), they cannot achieve their ambition. They thus contribute to fragmenting the territories and creating new spatial inequalities in terms of access to rights.

Only part of the PFR registered plot have a Land certificate. Much more, the new 2013 Land Code is clearly focused toward private ownership and access to title for urban people buying land. Rural Land Certificates are suppressed and only individual titles are possible. Village land management committees are asleep. Thus farmers' access to legal documents will stay an

\footnotetext{
${ }^{22}$ In Itagui, another administrative village/customary hamlet of the Dassa commune, autochthonous lineages from its customary center have succeeded in preventing the elaboration of the PFR and PFR operations were totally stopped.

${ }^{23}$ Only a part of the parcels registered in the PFR were issued a land certificate, due to the lack of interest from the villagers, complications at this stage, but also political obstruction at village level. Hence, in Léma, parcels were surveyed in the name of individual farmers, mostly migrants originating from neighboring villages. Customary authorities blocked the issuance of certificates. On the Dassa commune, in October 2016, a rural land certificate was established for only $47 \%$ of the surveyed parcels, and half of them were not collected by their bearers.
} 
exception and registered rights stay semi-formal, written in maps and books, but probably not updated (Lavigne Delville, 2014b). If and how much these new territories and land rights produced by the PFRs have concrete and lasting impacts on land relations between autochthons and migrants remains to document.

\section{Acknowledgements}

Fieldwork for this research have been partly funded by French National Agency for Research (ANR), within ANR APPI "Une action publique éclatée” research project.

\section{References}

Anignikin, S. C. (2001) 'Histoire des populations mahi. A propos de la controverse sur l'ethnonyme et le toponyme «Mahi »', Cahiers d'études africaines XLI(2 (162)): 243-65.

Bassett, T. (1993) 'Cartography, ideology and power: The World Bank in Northern Cote d'Ivoire', Passages 5: 8-9.

Bassett, T. (1995) 'L'introduction de la propriété de la terre : la cartographie et la Banque mondiale en Côte d'Ivoire' in C. Blanc-Pamard and L. Cambrézy (eds), Terre, terroir, territoire, les tensions foncières. Paris:Orstom.

Bassett, T. J., C. Blanc-Pamard and J. Boutrais (2007) 'Constructing Locality: The Terroir approach in West Africa', Africa 77(1): 104.

Bassett, T. J. and D. Gautier (2014) 'Territorialisation et pouvoir: la Political Ecology des territoires de conservation et de développement', EchoGéo (online) 29.

Benjaminsen, T. A. and E. Sjaastad (2008) 'Where to draw the line: Mapping of land rights in a South African commons', Political Geography 27(3): 263-79.

Berry, S. (1989) 'Social Institutions and Access to Resources in African Agriculture', Africa 59(1): 4155.

Berry, S. (2010) 'Property, Authority and Citizenship: Land Claims, Politics and the Dynamics of Social Division in West Africa' in T. Sikor and C. Lund (eds), The politics of possession. Oxford: Wiley-Blackwell.

Bierschenk, T. (2014) 'Sedimentation, fragmentation and normative double-binds in (West) African public services ' in T. Bierschenk and J. P. Olivier de Sardan (eds), States at Work. Leiden: Brill.

Bohannan, P. (1963) 'Land, Tenure and Land Tenure' in D. Biebuyck (ed.) African Agrarian Systems. Oxford: IAI/Oxford University Press.

Bosc, P.-M., J.-P. Chauveau, A. Yapi-Affou, A. Fian and P. d' Aquino (1996) Évaluation de l'opération pilote de plan foncier rural. Abidjan- Montpellier: Ministère de l'Agriculture et des ressources animales-CIRAD/SAR.

Bouju, J. (1991) 'Pouvoirs et légitimité sur le contrôle de l'espace rural. L'exemple du Ganzourgou (Burkina Faso)' in J.-P. Olivier de Sardan and E. Paquot (eds), D'un savoir à l'autre, les agents de développement comme médiateurs. Paris: GRET/Ministère de la Coopération.

Bouju, J. and R. Brandt (1989) Analyse socio-anthropologique des trames foncières dans la province du Ganzourgou. Ouagadougou: AVV Projet UP1-Zorgho.

Bromley, D. W. (2009) 'Formalising property relations in the developing world: the wrong prescription for the wrong malady', Land Use Policy 26(1): 20-27. 
Bruce, J. W. and S. E. Migot-Adholla. (1994) Searching for land tenure security in Africa. Washington: The World Bank.

Chauveau, J.-P. (2003). Rural Land Plans: Establishing relevant systems for identifying and recording customary rights. London: International Institute for Environment and Development.

Chauveau, J.-P. (2006) 'How does an institution evolve? Land, politics, intra-households relations and the institution of the tutorat between autochthons and migrant farmers in the Gban region (Côte d'Ivoire)' in R. Kuba and C. Lentz (eds), Landrights and the politics of belonging in West Africa. Leiden Brill Academic Publishers.

Chauveau, J.-P., P.-M. Bosc and M. Pescay (1998) 'Le plan foncier rural en Côte d'Ivoire' in P. Lavigne Delville (ed.) Quelles politiques foncières en Afrique rurale ? Paris: Karthala/Coopération française.

Chauveau, J.-P., J.-P. Jacob and P.-Y. Le Meur (2004) 'L'organisation de la mobilité dans les sociétés rurales du Sud', Gouverner les hommes et les ressources : dynamiques de la frontière. Autrepart 30(2): $3-23$.

Chauveau, J.-P. and P. Lavigne Delville (2012) Les limites des politiques de formalisation des droits fonciers et coutumiers (2) : L'illusion de la «photographie » neutre des droits. Les Notes de Politique de NEGOS-GRN 11. Nogent sur Marne: NEGOS-GRN/GRET/IRD.

Colin, J.-P., E. Léonard and P.-Y. Le Meur (2009) 'Identifier les droits et dicter le droit. La politique des programmes de formalisation des droits fonciers ' in J.-P. Colin, P.-Y. Le Meur and E. Léonard (eds), Les politiques d'enregistrement des droits fonciers. Du cadre légal aux pratiques locales. Paris: Karthala.

d'Aquino, P. (1998) 'Le traitement et la gestion de l'information foncière ' in P. Lavigne Delville (ed.) Quelles politiques foncières pour l'Afrique rurale? Réconcilier pratiques, légitimité et légalité. Paris: Karthala-Coopération française.

Edja, H. and P.-Y. Le Meur (2009) 'Le plan foncier rural au Bénin : connaissance, reconnaissance et participation' in J.-P. Colin, P.-Y. Le Meur and E. Léonard (eds), Les politiques d'enregistrement des droits fonciers. Paris: Karthala.

Elwert, G. and T. Bierschenk (1988) 'Development Aid as An Intervention in Dynamics Systems', Sociologia Ruralis 28(2/3): 99-112.

Gastaldi, J. (1998) 'Les plans fonciers ruraux en Côte d'Ivoire, au Bénin et en Guinée ' in P. Lavigne Delville (ed.) Quelles politiques foncières pour l'Afrique rurale? Paris: Ministère de la Coopération/Karthala.

Gautier, D. and B. Hautdidier (2012) 'Political ecology et émergence de territorialités inattendues: l'exemple de la mise en place de forêts aménagées dans le cadre du transfert d'autorité de gestion au Mali' in D. Gautier and T. A. Benjaminsen (eds), Environnement, discours et pouvoir: l'approche Political ecology. Versailles: Quae.

Godelier, M. (1978) 'Territory and property in primitive society', Social Science Information 17(3): 399-426.

Hochet, P. (2011) 'La terre, l'étranger et le citoyen. Des situations de citoyenneté associées à la terre' in E. Jul-Larsen, P.-J. Laurent, P.-Y. Le Meur and E. Léonard (eds), Une anthropologie entre pouvoirs et histoire. Conversations autour de l'oeuvre de Jean-Pierre Chauveau. Paris: APAD-IRD-Karthala.

Hochet, P. and L. Arnaldi di Balme (2012) 'La dialectique de l'étranger. La construction des relations contradictoires à l'étranger à la croisée des institutions coutumières et des politiques publiques dans l'Ouest du Burkina Faso', Autrepart 64(4): 55-70.

Hochet, P. and J.-P. Jacob (2014) 'Quelle place pour la reconnaissance des droits coutumiers dans la réforme foncière burkinabé ? Entre substitution et adaptation'. Paper presented at the Colloque final du projet de recherche ANR APPI, Toulouse, décembre 2014. 
Hounkpodote, R. M. (2002) 'Piloting the rural land-use plan in Benin' in C. Toulmin, P. Lavigne Delville and S. Traoré (eds), The dynamics of resource tenure in West Africa. London/Oxford/Portsmouth: IIED/James Currey/Heinemann.

Kopytoff, I. (1987). The African Frontier: the reproduction of African traditional societies. Bloomington: University of Indiana Press.

Kuba, R. and C. Lentz (2002) 'Arrows and earth shrines: towards a history of Dagara expansion in southern Burkina Faso', The Journal of African History 43(03): 377-406.

Lastarria-Cornhiel, S. (1997) 'Impact of privatization on gender and property rights in Africa', World development 25(8): 1317-33.

Lavigne Delville, P. (2009) 'Conceptions des droits fonciers, recits de politique publique et controverses. Les Plans fonciers ruraux en Afrique de l'Ouest' in J.-P. Colin, P.-Y. Le Meur and É. Léonard (eds), Les politiques d'enregistrement des droits fonciers. Du cadre légal aux pratiques locales. Paris: Karthala.

Lavigne Delville, P. (2010a) 'La réforme foncière rurale au Bénin. Émergence et mise en question d'une politique instituante dans un pays sous régime d'aide', Revue française de science politique 60(3): 467-91.

Lavigne Delville, P. (2010b) 'Sécurisation foncière, formalisation des droits, institutions de régulation foncière et investissements. Pour un cadre conceptuel élargi', Revue des Questions foncières (1): 5-34.

Lavigne Delville, P. (2014a) Competing conceptions of Customary Land Rights Registration (Rural Land Maps PFRs in Benin), Methodological, policy and polity issues. Cahiers du Pôle Foncier 5. Montpellier: Pôle Foncier.

Lavigne Delville, P. (2014b) 'Temps des politiques, temps des projets. Confusion des temporalités et contradictions institutionnelles dans la réforme foncière au Bénin (2005-2014)'. Paper presented at the Conférence finale du projet ANR APPI "Une action publique éclatée ?", Toulouse.

Lavigne Delville, P., J. Bouju and E. Le Roy (2000). Prendre en compte les enjeux fonciers dans une démarche d'aménagement : stratégies foncières et bas-fonds au Sahel. Paris: GRET.

Lavigne Delville, P., C. Toulmin, J.-P. Colin and J.-P. Chauveau. (2002) Negotiating Access to Land in West Africa: A Synthesis of Findings from Research on Derived Rights to Land; final report. London/Paris/Montpellier: IIED/GRET/IRD.

Le Meur, P.-Y. (2006) 'State Making and the Politics of the Frontier in Central Benin', Development and Change 37(4): 871-900.

Le Meur, P.-Y. (2011) 'Une petite entreprise de réassemblage du monde. Ethnographie et gouvernance des ressources foncières en Afrique de l'Ouest', Ethnologie française 41(3): 431-42.

Le Meur, P.-Y. (2012) 'Grandeurs villageoises: La politique des ressources et des appartenances au centre du Bénin', Cahiers d'études africaines (208): 877-903.

Lund, C. (2006) 'Twilight Institutions: Public Authority and Local Politics in Africa', Development \& Change 37(4): 685-705.

Lund, C. (2013) 'The past and space: On arguments in African land control', Africa: The Journal of the International African Institute 83(1): 14-35.

Manji, A. (2006). The politics of land reform in Africa: from communal tenure to free markets. London/New York: Zed Books.

Moalic, A.-C. (2014) 'Les enjeux locaux de la formalisation des droits fonciers en Afrique rurale. Analyse de la diversité des appropriations et réinterprétations du dispositif PFR : Cas des communes de Dassa et Savalou, Département des Collines, Bénin. Mémoire d'ingénieur, ISTOM.

Musembi, C. N. (2007) 'De Soto and land relations in rural Africa: breathing life into dead theories about property rights', Third World Quarterly 28(8): 1457-78. 
Olivier de Sardan, J.-P. (2005). Anthropology and Development: Understanding Comtemporary Social Change. London: Zed Books.

Painter, T., J. Sumberg, Price and Thomas (1994) 'Your terroir and my 'action space': implications of differentiation, mobility and diversification for the approche terroir in Sahelian West Africa', Africa 64(4): 447-64.

Peluso, N. L. and C. Lund (2011) 'New frontiers of land control: Introduction', The Journal of Peasant Studies 38(4): 667-81.

Platteau, J.-P. (1996) 'The Evolutionary Theory of Land Rights as Applied to Sub Saharan Africa: A Critical Assessment', Development and Change 27(1): 29-86.

Sack, R. D. (1986). Human territoriality: its theory and history. Cambridge: Cambridge University Press.

Scott, J. (1998). Seeing like a State. How Certain Schemes to Improve the Human Condition Have Failed. New Haven \& London Yale University Press.

Wily, L. A. (2016) 'Customary tenure: remaking property for the 21st century' in M. Graziadei and L. Smith (eds), Comparative Property Law: Global Perspectives. Cheltenham, UK: Edward Elgar Publishing.

Yngstrom, I. (2002) 'Women, wives and land rights in Africa: Situating gender beyond the household in the debate over land policy and changing tenure systems', Oxford Development Studies 30(1): 2140. 